\title{
Editorial
}

\section{Neoliberalism Within Psychology Higher Education in Indonesia: A Critical Analysis}

\author{
Teguh Wijaya Mulya \\ Faculty of Psychology Universitas Surabaya
}

\begin{abstract}
Critical scholars have demonstrated the ways in which neoliberalism has increasingly become a dominant organising principle in current global political, economic, and social practices, including in higher education. This article aims to explore how and to what extent neoliberal discourses have operated in a specific context, namely, in psychology higher education in Indonesia. To this end, the author examined policy documents published by relevant authorities such as AP2TPI, Dirjen DIKTI, and BAN-PT; and reflect on how those policies were enacted in the author's 10-year experience as a psychology lecturer in a university in Indonesia. The results show that neoliberal discourses such as standardisation, competitiveness, and market orientation have underpinned the policies, curricula, and practices of psychology higher education in Indonesia. The author argues that such discourses (re)produce psychology students, graduates, and lecturers who are competitive, result-oriented, and market-driven. Consequently, democratic, humane, and organic ways of learning and practicing psychology have given way to more mechanistic, standardised, and box-ticking approaches to human behaviour.
\end{abstract}

Keywords: neoliberalism, psychology, higher education, Indonesia

Para peneliti kritis telah membuktikan bahwa neoliberalisme telah menjadi prinsip yang dominan dalam dunia global kontemporer baik dalam praktik-praktik politik, ekonomi, maupun sosial, termasuk di ranah pendidikan tinggi. Artikel ini bertujuan untuk mengeksplorasi bagaimana dan sejauh mana wacana-wacana neoliberal telah beroperasi di sebuah konteks spesifik, yaitu pendidikan tinggi psikologi di Indonesia. Untuk itu penulis menganalisis dokumen kebijakan dari otoritas yang relevan seperti AP2TPI, Dirjen DIKTI, dan BAN-PT, serta merefleksikan bagaimana kebijakan-kebijakan tersebut terwujud dalam sepuluh tahun pengalaman penulis sebagai dosen psikologi di Indonesia. Hasil penelitian menunjukkan bahwa wacana-wacana neoliberal seperti standardisasi, daya saing, dan orientasi pasar telah mendasari berbagai kebijakan, kurikulum, dan praktik pendidikan tinggi psikologi di Indonesia. Penulis berargumen bahwa wacana-wacana ini me(re)produksi mahasiswa, lulusan, dan dosen psikologi yang kompetitif, berorientasi ke hasil, dan digerakkan oleh pasar. Akibatnya, pendekatan belajar dan praktik psikologi yang demokratis, manusiawi, dan organik telah digantikan oleh pendekatan yang lebih mekanistis, terstandar, dan sekadar mencentang kotak (box-ticking).

Kata kunci: neoliberalisme, psikologi, pendidikan tinggi, Indonesia

The 27th ASEAN Summit on the 22nd of November 2015 in Kuala Lumpur witnessed the formal establishment of ASEAN Economic Community (AEC), which is one of the milestones towards the full integration of Southeast Asian countries into a single mar-

Correspondence concerning this article should be addressed to Teguh Wijaya Mulya, Faculty of Psychology Universitas Surabaya, Jalan Raya Rungkut Mejoyo, Surabaya 60293. E-mail: teguh@staff.ubaya.ac.id ket and production basis (ASEAN, 2015). Throughout 2015-2016, discussions and concerns around the establishment of AEC were prevalent in Indonesian mass media and everyday conversations (e.g., Googie, 2015, November 26; Juwana, 2016, February 13). One of the main concerns was whether Indonesian products, services, labour, and professionals can compete with those from other ASEAN countries. The 
common response to this concern is that Indonesian national competitiveness (daya saing bangsa) must be increased, particularly through business-and-industry-oriented education (Humas Ristek, 2015, January 8). For instance, the Rector of Universitas Gadjah Mada (UGM) has recently stated that in order to anticipate AEC, the strategic direction of UGM has been reoriented from research-based university to a socio-entrepreneurial university, where research and programmes with commercial potential and/or industrial benefits are prioritised (Humas UGM, 2016, September 21).

In contrast to the common response of increasing economic competitiveness, in this article the author offered a critical analysis of the influence of global politics of the free market on higher education practices in Indonesia, that is, through the notion of neoliberalism.

Giroux (2002) states that neoliberalism is probably the most pervasive and dangerous ideology of the twenty-first century, not only because of its influence on the global economy, but also because it has redefined major parts of our contemporary political, societal, and psychological lives. Neoliberalism broadly means "the agenda of economic and social transformation under the sign of the free market" (Connell, 2013, p. 100). It is based on the assumption that human well-being can be achieved by encouraging an individual's entrepreneurial autonomy and freeing business from regulations that inhibit the pursuit of profit (Harvey, 2005). Neoliberal governments typically promote free market ideologies, including free trade, deregulation, tax reduction, and privatisation of public services. Neoliberalism works to reduce the role of the state in regulating the capitalist economy and replace this with the free market mechanisms, not just in relation to the economy but also to other social-political spheres. This expansion of market logics and mechanisms can be seen, for instance, in the language and practices of buying and selling in the areas previously not associated with profit and commercialism (Connell, 2013), such as education, health, and even prison services. At the psychological level, neoliberalism defines personhood through discourses of consumption and commercially-produced lifestyles (Giroux, 2002). Competitive, entrepreneurial, and selfinterest orientation have become dominant ways of making sense of the self and relating to others. Increasingly, education is oriented to (re)produce these neoliberal ways of being and seeing.

In higher education (HE) contexts, neoliberalism manifests in ideas and practices which are now widely accepted among contemporary universities, such as in managerialism, financial autonomy, competition for students and funding, and standardisation/ audit to achieve accountability (Rosser, 2016; Verheul, 2002). In Indonesia, neoliberal HE reform began in 1997-98 after the bailout by the World Bank, IMF, and Asian Development Bank to save the Indonesian economy from a monetary crisis (Nuryatno, 2008; Sensenig, 2015). The bailout was accompanied by a pressure to restructure the relationships between the state and specific industries in Indonesia, including decentralisation and privatisation of public education in educational sector (Welch, 2007).

In $\mathrm{HE}$ context, the major milestone was decentralisation and privatisation of five major public universities in 1999, that is, University of Indonesia, Gadjah Mada University, Diponegoro University, Bandung Institute of Technology, and Bogor Institute of Agriculture (Susanti, 2011; Welch, 2007). One of the implications of this change was that these universities must compete to generate more income, as the subsidy from the government decreased. Such increased financial autonomy was then followed by a new regime of audit, standardisation, and managerialism (Gaus \& Hall, 2015; Rosser, 2016) which was also applied to other 3,015 private universities as well as 88 public universities all over Indonesia (Abdullah, 2011; Iskandar, 2011). This dominant regime of audit culture becomes more perceptible with the increasing role and authority of the Badan Akreditasi $\mathrm{Na}$ sional - Perguruan Tinggi (BAN-PT) who develops standards (both academically and managerially) and audits all HE study programs in Indonesia. For instance, the 2012 HE Law states that accreditation by BAN-PT is compulsory and without accreditation status, universities cannot issue certificates although their students have completed their degree (Rosser, 2016).

The most explicit statement demonstrating how neoliberal discourses have underpinned policies and strategic directions of Indonesian HE can be found in Satryo Sumantri Brodjonegoro's (2003) - the Director General for $\mathrm{HE}$ at the Ministry of Education 1999-2007 - publication in the World Bank and UNESCO's Task Force on Higher Education and Society website. Explaining Indonesian HE reform, Brodjonegoro (2003) stated:

The (university) system should be accountable to the public, demonstrated by high efficiency of its operation, quality and relevance of its outputs, and an internal management that is publicly transparent and comply with the acceptable standard of 
quality (abstract, para. 3).

All those programs focus on improving the quality and efficiency of HE through competitive development grants. Institutions write development proposals based on the results of self-evaluation which is prepared according to explicit standard and expectation (abstract, para. 4).

Universities no longer pursue knowledge for its own sake, rather, they provide qualified manpower and produce knowledge. With this new economically oriented paradigm, comes accountability. (para. 14). In this publication, Brodjonegoro - as the top leader of the Indonesian HE system from 1999 to 2007 - draws on neoliberal discourses in explaining how Indonesian $\mathrm{HE}$ should be. Business-like language, such as "accountable," "efficiency," "management," and "qualified manpower" (sic), dominates his talk about Indonesian HE. He explicitly states that the pursuit of academic knowledge should be "economically oriented," so that knowledge production in universities should not be "for its own sake." It appears that economic benefits are positioned as the only valid reason for research activity. His talk also put neoliberal ideas of standardisation, audit, and selfevaluation at the heart of HE practices, which he believes are crucial to achieve accountability and quality outputs. Another neoliberal virtue, competitiveness, is also of paramount importance in Brodjonegoro's understanding of good HE practices.

Neoliberal HE reform in Indonesia has been studied by some researchers, and their analyses can be categorised into at least two camps. The first camp is the group of researchers who, like Brodjonegoro, see this reform as mainly beneficial for Indonesian HE. Jacob, Wang, Pelkowski, Karsidi, and Priyanto (2012), for example, mapped challenges and opportunities in reforming HE in Indonesia, with the purpose of advancing such reform. In a similar vein, Sulistiyono (2007) has claimed that neoliberal HE reform is not just inevitable when the Indonesian "economy is integrated into world market" (pp. 1011), but also "contributes to the development of a democratic, civilised, inclusive society," "nourishes participation of stakeholders," and "provides opportunities for all citizens to a faultless learning process" (p. 15).

In contrast, the second camp takes a more critical stance towards this reform. Some researchers in this camp have demonstrated and criticised how privatisation of Indonesian HE results in increasingly unequal access to HE (Abdullah, 2011; Susanti, 2011;
Welch, 2007). With most public universities offering jalur khusus/ekstension (where students who are willing to pay higher fees can be accepted) as their main admission avenue, these researchers argue that for most people, HE has become a luxury. Other researchers in this area critiqued the neoliberalisation of $\mathrm{HE}$ by identifying some negative consequences, such as the damaging of academic values and collegiality, the compromising of research findings to maintain good relationships with funders, and the importance of moral and social missions of HE is superseded (Mappiasse, 2014; Susanti, 2011).

At the individual level, Gaus and Hall (2015) specifically investigated the effect of neoliberal HE accreditation system on academics' sense of identity. Their finding showed that many lecturers perceived that the external accreditation standards imposed $\mathrm{u}$ pon them impacted on their personal intrinsic motivation to teach. They also felt that they were treated like a "little kid" (p. 675) or distrusted subjects by the government through the details of audit they must go through. Some senior academics felt undervalued by the one-size-fits-all approach of the BAN-PT, rendering their years of service insignificant if they do not fulfil the new criteria of work performance.

This article aims to extend the work of researchers in the second camp by exploring the operation of neoliberal discourses in a specific context, namely, psychology HE in Indonesia. While to some extent the findings and critiques in this study might resonate with those the author introduced above, this article seeks to speak to the community of psychologists and psychology educators in Indonesia which, in the author's ten years of experience working in this area, have been underexposed to such critiques. The current study pursues this aim by examining specific documents from authorities pertinent to psychology HE in Indonesia such as the AP2TPI (Asosiasi Penyelenggara Pendidikan Tinggi Psikologi Indonesia/Association of Indonesian Psychology Higher Education Providers).

Additionally, to complement previous studies that have mainly conducted at the macro level (i.e., national HE policies), the article also examines everyday educational practices in contemporary psychology HE in Indonesia. By investigating the operation of neoliberal discourses within this context, it is expected that this article will inspire explorations of more critical, ethical, and humane approaches to psychology HE in Indonesia, and more generally, to human behaviour and social relationships. 


\section{Method}

The methodology of the current study was built upon certain paradigmatic assumptions, that is, those of the critical paradigm (Guba \& Lincoln, 1994). In this paradigm, social reality is not understood as fixed or permanent, but as versions of reality constituted by language and discourses available in a specific cultural and historical context. There is no objective "truth" or factual knowledge independent from the knower's ways of knowing, rather, regimes of truth are (re)produced by the dominant power relations (Foucault, 1978). Following this ontological and epistemological stance, the methodology of this study did not aim to identify "truth" or "fact" (e.g., whether or not Indonesian HE is neoliberal). Instead, it sought to reveal what (neoliberal) discourses operating underneath taken-for-granted knowledge and social practices (within Indonesian psychology HE), and what the consequences might be.

To this end, the current study employed two qualitative data production methods. The first was document analysis, where relevant policy documents were scrutinised with the focus of identifying discourses given rise to those policies. Only documents that are publicly available on the Internet were analysed. These included policy documents from the BAN-PT, AP2TPI, KKNI (Kerangka Kualifikasi National Indonesia/Indonesian National Qualification Framework), Dirjen DIKTI (Direktorat Jenderal Pendidikan Tinggi/Directorate General for Higher Education), and LPDP (Lembaga Pengelola Dana Pendidikan/Educational Fund Managing Body); which were chosen based on their relevance or regulatory function within psychology HE. The BANPT works under the Ministry of Education to accredit all HE study programs in Indonesia. The AP2TPI is the association of Indonesian psychology HE providers that aims to coordinate, regulate, and develop all psychology HE in Indonesia. The KKNI is a group of policy documents published by the Ministry of Research, Technology, and Higher Education that defines and standardises learning outcomes of all Indonesian HE study programs, and is frequently referred to in psychology HE curricula in Indonesia. The Dirjen DIKTI is a governing body under the Ministry of Research, Technology, and Higher Education that is in charge of HE in Indonesia. The LPDP is a governing body under the Ministry of Finance that manages a proportion of national education fund. In this study, at least seven documents were downloaded and analysed: (a) BAN-PT's (2009) accredit- tation form (Borang Akreditasi Program Studi Sarjana); (b) AP2TPI's (2011) article of association (anggaran dasar); (c) AP2TPI's (2015) decree (surat keputusan) on psychology HE curriculum; (d) AP2TPI's 20th general meeting document (Kolokium, 2010); (e) legal basis (landasan hukum) of KKNI (Ristekdikti, 2015); (f) Dirjen DIKTI's (2016) guideline for research and community development; and (g) LPDP's (2016) guideline for innovative and productive research.

The second method was a reflective research method (Alvesson \& Sköldberg, 2009, p. 9) which involves "careful interpretation and reflection" on the author's own experience of being a psychology lecturer in a university in Indonesia. This experiential account might include the author's thoughts, feelings, acts, conversations with colleagues and students, written sources the author read, pictures the author saw, or spoken words the author heard during his work as a psychology lecturer. Such critical self-exploration is a less systematic form of qualitative data production (compared to interviewing, for example), as reflections to what happen anytime and anywhere.

In the case of this study, a reflective method was undertaken through the use of a reflective journal, which was then read, coded, and analysed using thematic analysis techniques (Braun \& Clarke, 2006). The focus of the analysis was the theoretical, political, discursive, and/or ethical aspects of the author's subjective experiences (Alvesson \& Sköldberg, 2009). These reflective data would be presented in ethnography-like manner, where the author's feelings, observations, and experiences were woven directly into the analyses.

Consistent with the critical paradigm of this study, the credibility of the data was not evaluated in terms of how "objectively" the data represented the "real" situation. Instead, the credibility of the data was understood in relation to its relevance in answering the research questions, its logical connection with the claims or arguments displayed in this article, and the sense of connectedness of the readers with their experiences of being a part of psychology HE in Indonesia (Willig, 2013).

\section{Results}

In presenting the findings below, the author's intention is to display policies and educational practices with which psychology educators and policy- 
makers might be familiar. The author sought to demonstrate that there were neoliberal discourses underneath these taken-for-granted knowledge and practices, and describe what the discursive consequences might be. The analyses revealed at least three neoliberal discourses operating within the policies around psychology HE in Indonesia, namely, market orientation, competitiveness, and audit/standardisation. These discourses were also manifested in everyday educational practices in the author's experiences working as a lecturer in a faculty of psychology in Indonesia. The current section will discuss each of these discourses.

\section{Market Orientation}

To be able to entrepreneurially sell themselves and survive in the market, neoliberal HE institutions must continuously identify and (re)orient their efforts to satisfy what the market wants. Universities need to offer products and services that match with what their "consumers," stakeholders, and other sources of funding want, including parents, governments, companies, or donors that may contribute to their income. Since the main mission of Indonesian HE is supposedly to "provide qualified manpower" [sic] for business and industries (Brodjonegoro, 2003), universities must be able to "sell" their graduates to the labour market and maintain their reputation as providers of skilled workforces. In this section, the author argues that this neoliberal discourse of market orientation has constituted dominant ways of thinking within psychology HE policies and practices in Indonesia.

A strong orientation toward global labour market has characterised psychology HE policies, such as AP2TPI and KKNI's policy documents. The preamble of AP2TPI's articles of association (2011), for instance, states that the reason for establishing this association is the need "to formulate psychology educational system in Indonesia which is able to anticipate current developments, especially in facing the free market/merumuskan sistem pendidikan psikologi di Indonesia yang antisipatif dengan perkembangan yang ada, khususnya dalam menghadapi pasar bebas" (p. 4). It is evident that from the outset AP2TPI considers global free market as the main reason to (re)formulate psychology HE system in Indonesia.

Similarly, the legal basis of KKNI (Ristekdikti, 2015 , p. 4) explains that one of the main purposes of KKNI is to "encourage quality improvement and accessibility of Indonesian human resources for national and international labour market/mendorong peningkatan mutu dan aksesibilitas sumberdaya manusia Indonesia ke pasar kerja nasional dan internasional," and therefore, universities are responsible to "produce qualified human resource for industry sectors, business, or government/menghasilkan sumberdaya manusia yang bermutu bagi sektor-sektor industri, dunia usaha atau pemerintahan" (p. 3). As these documents show, the ways that policymakers understand the purpose of $\mathrm{HE}$ - including psychology HE - are dominated by an orienttation toward business and industry. The purpose of HE is constituted as merely producing skilled workers who are ready to be absorbed into the labour market. Accordingly, one of the accreditation standards from the BAN-PT (Standar 3.3.2) is the speed of graduates absorbed into relevant workforces (BAN-PT, 2009). The shorter the waiting time of graduates attaining their first job, the higher the accreditation score.

In the curriculum, these labour market-oriented policies are expressed in graduates' work prospects or professions (prospek kerja lulusan) described as a departing point and an ending point of the whole learning process, started from the learning outcomes to the learning assessment. The student academic handbook in the author's faculty, for example, begins with eight professions that our psychology graduates commonly held, namely, assistant manager, counsellor, teacher, entrepreneur, trainer, community organizer, researcher, and assessor (Ubaya, 2016, p. VIIId.3.1). This handbook follows the AP2TPI's (2015) decree/surat keputusan on psychology HE curriculum Chapter 2 Article 2 that specifies ten potential jobs for a bachelor of psychology as the basis to develop standardised learning outcomes. In term of the output, the BAN-PT's (2009) accreditation standard 3.3.3 evaluates the quality of the study program based on how many graduates work in the jobs that have been declared relevant to (psychology) HE. In this way, the curriculum is considered good when it meets the needs of the labour market, and when the efforts to improve the curriculum are concertedly directed at this goal.

Regarding research, university lecturers have been strongly encouraged to conduct studies that are relevant to business, industry, and the labour market. Two government agencies distributing the largest proportion of national research funding, the Dirjen DIKTI and LPDP, have explicitly expressed more interests in funding research that can be "commerci- 
alised/implemented" or patented (e.g., LPDP, 2016, p. 4) than "basic research." When the CEO of LPDP, Eko Prasetyo, visited the author's university, he summarised the national research policy in two words: downstreaming (hilirisasi) and commercialisation. By controlling research funding, the government drives academics to prioritise research that focuses on what the business markets want, and leaves other research orientations (e.g., critical research like this study) unfunded. Fortunately, there are still alternative research schemes such as DIKTI's Hibah Penelitian Fundamental and DIPI (Dana Ilmu Pengetahuan Indonesia) that provide funding for basic research. As Connell (2013) has noted, neoliberalism results in a decline in academic disciplines or theoretical perspectives that do not attract million-dollar research grants; specifically in terms of the number of students, the amount of funding, and knowledge production.

The dominant discourse of market orientation in Indonesian HE has brought both positive and negative consequences. On the brighter side, previous studies have shown that an orientation toward the market in the Indonesian HE context has made universities pay more attention to the need of students and their parents, strive for quality outcomes rather than quality inputs, and produce practically useful products from research (Susanti, 2011). It also brings universities in closer collaboration with businesses and industries, so that this enables graduates to attain a job more easily. On the darker side, a strong focus on commercialisation inhibits the sense of creativity and critical thinking of researchers (Gaus \& Hall, 2015). The discourse of market orientation also encourages students and graduates to "sell" themselves to profit-oriented enterprises rendering other lower-paid jobs, such as becoming NGO activists or community workers, undesirable.

An orientation toward what the market want and pursuing high-paying jobs might also result in the ignorance of unethical practices within the company. This can be seen from discriminatory practices during employee recruitment and selection, which is based on ethnicity and physical attractiveness according to our faculty's graduates. Another unethical practice by companies that has become a common secret in Indonesia is paying employees below the minimum wages. With respect to this issue, the graduates told me that those who want to keep their job usually stay silent. Unfortunately, the purpose of psychology HE is apparently not about creating individuals who confront inequality and discrimina- tion, but producing self-interested individuals who are ready to compete in the market - for money, status, and achievement.

\section{Competitiveness}

The second neoliberal discourse that, the author argued, has given rise to policies and practices of psychology $\mathrm{HE}$ in Indonesia is competitiveness. Neoliberalism valorises competitive individuals and organisations who persistently strive to achieve status and profit in the free market. In the HE context, universities are pitted against each other, competing to attract students and funding. In this section, the author will demonstrate how competition and competitiveness have been seen as desirable qualities within Indonesian psychology HE policies and practices.

The CEO of LPDP began his talk in the author's university with a graph describing Global Competitiveness Index (GCI) of several countries including Indonesia. He then used Indonesian low GCI (compared to other Southeast Asian countries) as the main reason to invest and improve our HE system. This rhetorical gesture is common in Indonesian HE policies, such as how the term "national competitiveness/daya saing bangsa" dominates the AP2TPI's articles of association (2011), legal basis of KKNI (Ristekdikti, 2015), and Dirjen DIKTI's guideline for research and community development (2016). In these documents, competition and competitive individuals are positioned as inherently good for the advancement of Indonesian HE.

At the university level, a discourse of competitiveness gives rise to the ways of thinking that encourage students and lecturers to join competitions; and when they win, their achievements are displayed to strengthen the university's reputation. The author's university's website, for example, always shows photos of students winning various competitions and lecturers receiving awards. Another university even put such achievements in extra-large billboards on the road near their campus. In the author's faculty, all students are required to join Dirjen DIKTI's competition Program Kreativitas Mahasiswa (PKM) at least twice during their study, with the hope that some of them might win the competition.

The dean and other faculty representatives are also expected to continuously tell their students', lecturers', faculty's, and university's achievements in every opportunity or during their speech. Along- 
side those achievements, our international collaboration with a university in China is often highlighted, showing that we are able to compete and collaborate at the international level. In this age of neoliberalism, impression management and displaying achievement as such have become basic survival strategies for universities to win the competition for students and funding. Accordingly, the BAN-PT promotes competitiveness by including students' achievements and lecturers' winning for competitive grants as a part of the accreditation standard (Standar 3.2.2 \& 4.5.5, BAN-PT, 2009).

While a competition is not fundamentally destructive, the author argues that an overemphasis on competitiveness might draw attention away from values that have been held as a core in the social purpose of the university. While the author is cognisant that competitiveness might energise students and lecturers to be innovative, creative, and successful, there are other consequences that need to be considered. For example, what kind of value does the contemporary university place on the exploration of ideas, practices of collegiality, and enactment of democratic values? With universities defined as companies competing with each other, $\mathrm{HE}$ institutions cannot be controlled by educators whose intention is to better democratic society, but instead are controlled by entrepreneurs or managers who are competent in advertising, budgeting, and making money (Connell, 2013).

An achievement that grows out of internal motivation to improve or mutual purpose is no longer appreciated, because achievement is mainly about building reputation and impressing the market (Apple, 2005). Democratic and critical education is replaced with training of skills needed to compete in the labour market, that is, a competition for privilege and social conformity (Connell, 2013). These forces of competition only (re)produce the hierarchy of class and exclusions, which contradict the inclusive and egalitarian spirit of education (Apple, 2005). Unfortunately, as this section has shown, competition and competitiveness have been held in high regard within the Indonesian psychology HE system.

\section{Audit/Standardisation}

To maintain accountability with stakeholders and funding sources, neoliberal universities need to demonstrate the quality of their work using performance criteria or standards that can be evaluated, measured, and compared. To achieve this, an audit culture is established to (re)produce self-surveilling individuals who continuously monitor and adjust themselves to follow externally imposed standards and goals. The final neoliberal discourse the author unpacked in this article is the discourse of audit and standardisation which has been increasingly dominant in the Indonesian HE system, including psychology HE.

A discourse of standardisation has been circulating and - to some extent - has gained a status of "common sense" within the Indonesian psychology HE policy in the last decade. Besides the significant role of the BAN-PT that the author has discussed in the Introduction, the AP2TPI has also become the beacon of standardisation for psychology $\mathrm{HE}$ in Indonesia. For instance, in the 20th general meeting AP2TPI declared that its long-term goal is to "ensure that all (psychology) HE institutions in Indonesia have equal standards/memastikan standar tiap perguruan tinggi di semua daerah di Indonesia merata" (Kolokium, 2010, p. 1). Such standards include competencies that must be attained by all psychology graduates, learning outcomes that must be measured, and learning materials that must be taught to psychology students (AP2TPI, 2015). It has been increasingly unthinkable to discuss HE improvement without focusing on developing and enforcing standards; and those standards are assumed as objective and good for all. The standards refer to the ones developed by the AP2TPI whose main officials are dominated by those from top universities in Indonesia (both public and private universities), such as UI, UGM, Unpad, Unair, and Ubaya. Helping all faculties of psychology in Indonesia to comply with these standards means enforcing the decisions made by these dominant groups to all other psychology $\mathrm{HE}$ institutions in Indonesia.

In addition to the policy, the discourse of standardisation has also penetrated everyday educational practices, including the author's experiences working in the faculty of psychology. In 2016's end-of-year meeting in the author's faculty, the plans for the following year were frequently justified using the phrase "because we are still lacking on this point in the accreditation standards." For example, one of our plans was a major revision to the curriculum "to make it more consistent with the standards." Similarly, when the author was the head of the General Psychology Laboratory a few years ago, the author considered the BAN-PT accreditation standards as the main driver of all activities, programmes, budgeting, and even as the main sour- 
ce of our sense of accomplishment. In this way, the discourse of standardisation (re)produces self-surveilling individuals who excitedly put themselves under the regime of audit and mobilise all efforts to achieve those externally imposed goals.

Crucial to the standardisation of HE, the establishment of audit culture, for which the author has been argued, has played a dominant role in the Indonesian HE system. Due to the high-stakes audit by the BAN-PT applied to every study programme, site visits by BAN-PT assessors were usually prepared to the finest details, from the welcoming banner stating the full name and titles of the assessors to the well-decorated displays of achievements and physical evidence of each accreditation standard. When the accredited status is attained, this is celebrated as a significant success of the faculty - we joyfully congratulated each other. For the author, such experience is reminiscent of what Apple (2005) called the society of auditees who anxiously waits to be audited by the neoliberal regime. Further, to internalise the audit culture that the BAN-PT has imposed on, the accreditation standards require universities to have an internal quality assurance unit who monitors and audits all aspects of university's activities both academically and managerially, including lecturers' research performance, compliance to standard operating procedures in all services to students, and standardisation of learning process in the class (BAN-PT, 2009). An example of those that need to be monitored and audited is the detailed syllabus that should be followed by lecturer minuteby-minute, and the students - positioned as consumers - evaluate their lecturer based on those syllabi.

This regime of standardisation and audit has transformed the Indonesian HE system, both positively and negatively. To a degree, they have made HE institutions more accountable and more efficient, which are considerably important considering that the bureaucratic culture has been historically dominant among Indonesian public universities (Susanti, 2011). Standardisation also enables HE institutions to manage and control their mass production of skilled workers; and makes it easier for companies to evaluate, sort, and absorb these potential workers. However, previous studies have shown that the imposition of standards (which are defined by the dominant groups) to all other universities have often resulted in data manipulation (Gaus \& Hall, 2015; Rosser, 2016; Welch, 2007), particularly by lessresourced universities who desperately need the accreditation status to survive in the market.
Pedagogically, the standardisation of learning processes has marginalised organic, critical, and reflective approaches to education, and promoted mechanistic-technicised learning, that is, measuring and harsh-drilling of specific competencies (Connell, 2013). Equal and respectful dialogues between lecturers and students become less important, and are replaced by one-way instant transfers of knowledge in order to achieve quantifiable targets. Some of the author's students, for example, appear to be more concerned about learning assessment criteria rather than forming a deep conceptual understanding of the topic at hand. Instead of seeking to create humane and ethical individuals who recognise the complexities of social life, universities have increasingly worked to (re)produce box-ticking robots.

\section{Conclusion}

There is a phrase that was occasionally mentioned by some of the author's students about the purpose of learning psychology. They said it is "to humanise humans (memanusiakan manusia)," which means treating humans humanely. The author agrees with this idea, and the author considers it is what makes psychology education unique. Different from other HE majors, such as business and economics that see humans mainly as consumers or resources, psychology sees humans as humans. Unlike engineering faculties that generally position humans as users of technology, psychology positions humans as humans. In contrast to medical school that usually approach humans as a collection of intercomnected organs that may or may not function properly, psychology (cl)aims to engage with humans as humans.

Considering psychology's unique and holistic approach to human beings, psychologists and psychology educators cannot and should not ignore the creeping of neoliberal ideology which has a dehumanising tendency, that is, reducing and (re)producing human beings merely as entrepreneurial, selfinterested, and competitive. Resisting these neoliberal discourses, psychology education should not only provide students with skill training, such as counselling, coaching, interviewing, or constructing psychometric measurements, but also help students to understand cognitive, biological, behavioural, social, cultural, political, and ideological mechanisms behind a human's behaviour, with the purpose of encouraging a more humane treatment to human beings. While standardisation might be beneficial to 
psychologists' professional works, it is also crucial to question the discursive impacts of excessive standardisations on human relations and wellbeing.

This article has demonstrated how three neoliberal discourses have given rise to various aspects of psychology HE policy, curriculum, and practices in Indonesia, namely, a discourse of market orienttation, competitiveness, and standardisation/audit. It has provided evidence how these discourses are dominant in this context by examining relevant policy documents and the author's own experiences. Considering that the method used in this study produced only limited data, future studies should expand the methodology of the current study by exploring this topic from students' perspectives or experiences, such as the ways the neoliberal discourses both enable and constrain their learning processes.

Recognising how psychology HE in Indonesia has been underpinned by neoliberal discourses is only a first little step into the de-stabilisation of the neoliberalisation of education in Indonesia. The next step that future studies might need to undertake is exploring alternatives to this neoliberal education, particularly based on the Indonesian local contexts. This exploration is crucial as some proponents of neoliberalism have repeatedly highlighted the impossibility of other alternatives. For example, Sulistiyono (2007) accused critics of neoliberalisation of Indonesian $\mathrm{HE}$ as being preoccupied with "romantic and historic way of thinking" and "not looking at the situation in realistic way" (p. 12). The "situation" that he referred here is the global free market that cannot be stopped and the condition of Indonesian government that has no "economic capability to finance expensive qualified and internationalised standard of HE" (p. 15). While the author believes there is no simple and straightforward way to challenge the dominant discourse of neoliberalism in the HE context, persistently exploring cracks and fissures in its regulatory regime might generate a certain degree of critical awareness, and eventually, new ways of thinking and seeing psychology higher education.

\section{References}

Abdullah, I. (2011). Equity and access in a constantly expanding Indonesian higher education system. In D. Neubauer \& Y. Tanaka (Eds.), Access, equity, and capacity in Asia-Pacific high- er education (pp. 71-82). New York: Palgrave Macmillan.

Alvesson, M., \& Sköldberg, K. (2009). Reflexive methodology: New vistas for qualitative research. London: Sage.

AP2TPI. (2011). Pendirian perkumpulan Asosiasi Penyelenggara Pendidikan Tinggi Psikologi Indonesia (The establishment of Association of Indonesian Psychology Higher Education Providers). Retrieved from http://ap2tpi.or.id/index.php ?option=com_k2\&view=item\&id=44:pendirianperkumpulan-appt-fpsi-25-april-2011\&Itemid=118

AP2TPI. (2015). Keputusan Asosiasi Penyelenggara Pendidikan Tinggi Psikologi Indonesia (Decision of the Association of Indonesian Psychology Higher Education Providers). Makassar: AP2TPI. Retrieved from http://ap2tpi.or.id/index .php?option=com_k2\&view=item\&id=141:kolok ium-psikologi-indonesia-2015\&Itemid=53

Apple, M. W. (2005). Education, markets, and an audit culture. Critical Quarterly, 47(1-2), 11-29. http://dx.doi.org/10.1111/j.0011-1562.2005.00611.x

ASEAN. (2015). A blueprint for growth ASEAN economic community 2015: Progress and key achievements. Jakarta: The ASEAN Secretariat. Retrieved from http://www.asean.org/wp-content/uplo ads/images/2015/November/aec-page/AEC-2015 -Progress-and-Key-Achievements.pdf

BAN-PT. (2009). Borang akreditasi sarjana (Bachelor degree's accreditation form). Jakarta: BAN-PT. Retrieved from http://ban-pt.kemdiknas .go.id/download-program-studi

Braun, V., \& Clarke, V. (2006). Using thematic analysis in psychology. Qualitative Research in Psychology, 3(2), 77-101. http://dx.doi.org/10.11 91/1478088706qp063oa

Brodjonegoro, S. S. (2003). Higher education reform in Indonesia. Retrieved from http://www.tfhe.ne t/resources/satryo_soemantri_brodjonegoro2.htm

Connell, R. (2013). The neoliberal cascade and education: An essay on the market agenda and its consequences. Critical Studies in Education, 54(2), 99112. http://dx.doi.org/10.1080/17508487.2013.776990

Dirjen DIKTI. (2016). Panduan pelaksanaan penelitian dan pengabdian pada masyarakat edisi $X$ (Guideline for research and community development 10th ed.). Retrieved from http://lppm.ugm. ac.id/wp.../Panduan_Pelaksanaan_Penelitian_dan _PPM_Edisi_X_2016.pdf

Foucault, M. (1978). The history of sexuality, vol. 1: The will to knowledge (R. Hurley, Trans.). New York: Pantheon Books. 
Gaus, N., \& Hall, D. (2015). Neoliberal governance in Indonesian universities: The impact upon academic identity. International Journal of Sociology and Social Policy, 35(9/10), 666-682. http://dx.doi .org/10.1108/IJSSP-12-2014-0120

Giroux, H. (2002). Neoliberalism, corporate culture, and the promise of higher education: The university as a democratic public sphere. Harvard Educational Review, 72(4), 425-464. http://dx.doi.org /10.17763/haer.72.4.0515nr62324n71p1

Googie, A. (2015, November 26). Masyarakat ekonomI ASEAN, waspada "brain drain" (ASEAN economic community, watch for the brain drain), Kompas. Retrieved from http://bisniskeuangan. kompas.com/read/2015/11/26/130000726/Masyar akat.EkonomI.ASEAN.Waspada.Brain.Drain

Guba, E. G., \& Lincoln, Y. S. (1994). Competing paradigms in qualitative research. In N. K. Denzin \& Y. S. Lincoln (Eds.), Handbook of qualitative research (2nd ed., pp. 105-117). Thousand Oaks: Sage.

Harvey, D. C. (2005). A brief history of neo-liberalism. Oxford: Oxford University Press.

Humas Ristek. (2015, January 8). Mendorong perguruan tinggi dalam rangka menghadapi MEA (Encouraging universities in facing AEC). Retrieved from http://www.dikti.go.id/open-3/

Humas UGM. (2016, September 21). Inovasi meningkatkan daya saing dan kemandirian bangsa (Innovation to improve national competitiveness and independence). Retrieved from http://www. dikti.go.id/inovasi-meningkatkan-daya-saing-dan -kemandirian-bangsa/

Iskandar, H. (2011). Higher education reform in Indonesia. Paper presented at the Transforming tertiary education for innovation and competitiveness, Bali, 6-10 June 2011. http://siteresourc es.worldbank.org/EDUCATIONLP/Resources/4Harris_Iskandar-Perspectives_on_Higher_Educat ion_in_Indonesia.pdf

Jacob, W. J., Wang, Y., Pelkowski, T. L., Karsidi, R., \& Priyanto, A. D. (2012). Higher education reform in Indonesia: University governance and autonomy. In H. G. Schuetze, W. Bruneau \& G. Grosjean (Eds.), University governance and reform: Policy, fads, and experience in international perspective (pp. 225-240). New York: Palgrave Macmillan.

Juwana, H. (2016, February 13). MEA dan tantangannya (ASEAN Economic Community and its challenges), Kompas. Retrieved from http:// print.kompas.com/baca/opini/artike1/2016/02/13/ MEA-dan-Tantangannya

Kolokium. (2010). Keputusan sidang komisi kolokium psikologi XX (Decisions of the 20th congress of psychology colloquium). Bali: Kolokium. Retrieved from http://ap2tpi.or.id/index.php?opt ion $=$ com_k2\&view=item $\&$ task $=$ download $\&$ id $=9$ $\&$ Itemid $=116$

LPDP. (2016). Panduan riset inovatif produktif (Guideline for innovative and productive research). Jakarta: LPDP. Retrieved from http://www.lpdp.keme nkeu.go.id/wp-content/uploads/2013/09/Pedoman -Riset-Inovatif-Produktif-RISPR O.pdf

Mappiasse, S. (2014). Education reform in Indonesia: Limits of neoliberalism in a weak state. (Doctor of Philosophy), University of Hawaii, Honolulu.

Nuryatno, M. A. (2008). Freire and popular education in Indonesia: Indonesian Society for Social Transformation (INSIST) and the Indonesian volunteers for social transformation (involvement) program. In A. A. Abdi \& D. Kapoor (Eds.), Global perspectives on adult education (pp. 107124). New York: Palgrave Macmillan.

Ristekdikti. (2015). Landasan hukum kerangka kualifikasi nasional Indonesia (Legal foundation of Indonesian national qualification framework). Jakarta: Ristekdikti. Retrieved from http://kknikemenristekdikti.org/asset/pdf/002-dokumen_lan dasan_hukum_kkni.pdf

Rosser, A. (2016). Neo-liberalism and the politics of higher education policy in Indonesia. Comparative education, 52(2), 109-135. http://dx.doi.org/10.10 80/03050068.2015.1112566

Sensenig, V. J. (2012). The World Bank and educational reform in Indonesia. In C. S. Collins \& A. W. Wiseman (Eds.), Education strategy in the developing world: Revising the World Bank's education policy (pp. 395-421). Bingley, U.K.: Emerald Group Publishing Limited.

Sulistiyono, S. T. (2007). Higher education reform in Indonesia at crossroad. Paper presented at the Graduate School of Education and Human Development, Nagoya University, Japan, Nagoya, 26 July 2007. http://www.luk.staff.ugm.ac.id/atur/b hp/HEReform-Singgih.doc

Susanti, D. (2011). Privatisation and marketisation of higher education in Indonesia: The challenge for equal access and academic values. Higher Education, 61(2), 209-218. http://dx.doi.org/10.1007/s1 0734-010-9333-7 
Ubaya. (2016). Buku pedoman akademik (Academic guide book). Surabaya: Ubaya. Retrieved from http://ubaya.ac.id/2014/current_students/content/ guide.html

Verheul, H. (2002). Higher education reform in Indonesia: Integrating new public management and national values. In M. De Jong, K. Lalenis \& V. Mamadouh (Eds.), The theory and practice of institutional transplantation (pp. 185-198). Dordrecht: Kluwer Academic Publishers.

Welch, A. R. (2007). Blurred vision?: Public and private higher education in Indonesia. Higher Education, 54(5), 665-687. http://dx.doi.org/10.1007/ s10734-006-9017-5

Willig, C. (2013). Introducing qualitative research in psychology. Berkshire: Open University Press. 